\title{
O ESTADO DE COISAS INCONSTITUCIONAIS: Caminhos Adotados pelo Judiciário Brasileiro
}

\author{
http://dx.doi.org/10.21527/2176-6622.2019.52.236-250
}

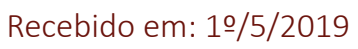

Modificações requeridas em: 26/10/2019

Aceito em: 4/11/2019

\section{Renata Miranda Lima}

Advogada. Mestranda pela Universidade Nove de Julho em Direito (2018). Pós-graduada pela Universidade Castilla La Mancha - UCLM em Negociação, Conciliação e Mediação em Resolução de Conflitos (2018). Pós-Graduada pelo Instituto Brasileiro de Ciências Criminais - IBCCRIM em parceria com o Instituto lus Gentium Conimbrigae (IGC) Centro de Direitos Humanos da Faculdade de Direito da Universidade de Coimbra, em Direitos Fundamentais Internacionais (2017). Graduada em Direito pela Universidade Nove de Julho - Uninove (2016). http://lattes.cnpq.br/9477688103206508. renatamirandalima@yahoo.com.br

\section{Carolina de Albuquerque}

Doutora em Ecologia Aplicada pela Universidade de São Paulo Esalq/Cena (2017). Mestre em Direito pela Universidade Metodista de Piracicaba (2006). Especialista em Direito Constitucional pela Pontifícia Universidade Católica de Campinas (2004) e bacharel em Direito pela Universidade de Mogi das Cruzes (2002). Doutoranda no Programa de Pós-Graduação em Direito Político e Econômico da Universidade Presbiteriana Mackenzie e professora do curso de Direito do Centro de Ciências e Tecnologia do Mackenzie Campinas. É autora do livro Direito fundamental à coisa julgada: problemas constitucionais de sua relativização. Tem experiência na área de Direito Ambiental e Direitos Humanos e Fundamentais. http://lattes.cnpq.br/6718630942660549. carolinadealbuquerque@yahoo.com.br

\section{RESUMO}

O presente estudo debruça-se sobre o sistema penitenciário brasileiro e as técnicas de decisão aplicadas pelo Supremo Tribunal Federal STF. A finalidade é discutir as complexidades que se colocam à atividade judicial no Direito Penal, tendo como recorte a Medida Cautelar da Ação de Descumprimento de Preceito Fundamental MC - ADPF 347. Nesse sentido, é feita uma análise crítica a respeito do posicionamento adotado pelo STF, como guardião da Constituição, os limites da sua atuação, os desafios para a concretização dos direitos fundamentais, bem como a observância do arranjo previsto constitucionalmente no que diz respeito à separação de poderes. Como passos finais da pesquisa é feita uma análise do cumprimento e instituição da decisão proferida pelo STF na ADPF 347 no Judiciário brasileiro até 2017. Destaca-se que o presente estudo parte do método dedutivo e adota como passos metodológicas a pesquisa bibliográfica e estudo de caso.

Palavras-chave: Sistema prisional brasileiro. Estado de coisas inconstitucional. Violação de direitos.

\section{THE STATE OF UNCONSTITUTIONAL THINGS: PATHWAYS ADOPTED BY BRAZILIAN JUDICIARY}

\section{ABSTRACT}

This study focuses on the Brazilian penitentiary system and the decision techniques applied by the Supreme Federal Court - STF. The purpose is to discuss the complexities of judicial activity in Criminal Law, having as its cut the precautionary measure of the action of breach of fundamental precept MC - ADPF 347. In this sense, a critical analysis is made regarding the position adopted by the STF, as guardian of the Constitution, the limits of its action, the challenges for the realization of Fundamental Rights, as well as the observance of the constitutionally provided arrangement regarding the separation of powers. As final steps of the research is made an analysis of compliance and implementation of the decision made by the Supreme Court in ADPF 347 in the Brazilian Judiciary until 2017. It is noteworthy that this study starts from the deductive method and adopts as methodological steps the bibliographic research and case study.

Keywords: Brazilian prison system. Unconstitutional state of affair. Violation of rights.

\section{SUMÁRIO}

1 Introdução. 2 A Construção da Figura do Estado de Coisas Inconstitucionais no Judiciário. 3 Análise da Petição Inicial e da Decisão Cautelar da ADPF 347. 4 Análise de Dados e Encaminhamentos do Judiciário após a ADPF 347/STF. 4.1 A Instituição das Audiências de Custódia no Brasil até 2017: Alínea "b" da Decisão Cautelar da ADPF 347 e os Presos Sem Condenação. 4.2 Um Estudo nas Varas de Execução Penal. 5 Conclusão. 6 Referências. 


\section{INTRODUÇÃO}

É centro das discussões, tanto no campo acadêmico como político, o estado de superlotação do sistema carcerário brasileiro, que a cada ano insere mais pessoas. Tal situação é corroborada por meio de dados doSistema Penitenciário Brasileiro ao informar que em 1990 o número de pessoas privadas de liberdade correspondia a 90.000 (noventa mil). Em 2000 o número foi para 232.800 (duzentos e trinta e dois mil e oitocentos). Em 2010 ocorreu o aumento de quase o triplo da população, com 496,300 mil em cárcere. Passados apenas quatro anos, ou seja, em 2014 o Brasil tinha uma população prisional de 622.202, ficando atrás apenas dos Estados Unidos, da China e da Rússia. Como forma de atualizar as informações, segundo recente pesquisa realizada, até junho de 2016 o Brasil contava com uma população cerceada de liberdade em 726.712 pessoas (BRASIL, 2016, p. 19).

Os dados supramencionados trouxeram à tona a necessidade de atenção ao sistema carcerário brasileiro, principalmente no que diz respeito ao estado de superlotação e ao déficit de vagas. Nesse contexto, a ADPF 347 provocou o Judiciário sobre um problema estrutural que exigiu do órgão jurisdicional uma articulação capaz de retirar os demais poderes da inércia. Ou seja, um provimento jurisdicional que extrapola o modelo comum de dizer o Direito.

Observa-se que a finalidade buscada na ADPF 347 é a redução das violações generalizadas constatadas na ação constitucional. Nesse sentido, o STF detecta que o estado de superlotação fere direitos da população encarcerada e causa prejuízos sociais, incumbindo à Corte e ao Judiciário relevante função para a redução deste estado de violação.

Salienta-se que tal reflexão ocupou relevante porcentagem da decisão cautelar proferida pelo STF na ADPF em estudo, a qual trouxe encaminhamentos que exigem ações dos três poderes, mas há especial atenção de encaminhamentos ao Judiciário brasileiro, pois deste se requer ações acompanhadas de um novo pensar, entre as quais salienta-se a necessidade da audiência de custódia bem como a redução na aplicação de prisões às pessoas sem condenação.

A atenção despendida para o Judiciário na decisão cautelar se justifica, porque a este cabe o exercício da palavra final do dizer o Direito e por ser órgão estratégico à redução ou aumento do estado inconstitucional constatado, pois apenas juízes têm competência, conferida legalmente, para encarcerar pessoas e aplicar medidas cautelares à prisão.

Dizer o Direito, contudo, e construir soluções jurídicas às questões referentes ao sistema carcerário brasileiro, não tem se mostrado um caminho fácil e exige criatividade. Por isso tal situação tem fomentado o desenvolvimento de novas formas de decidir quando a situação é posta ao Judiciário.

Nesse sentido, o presente estudo objetiva compreender a situação concreta de pessoas encarceradas e o sistema prisional brasileiro, as construções jurídicas decorrentes da Medida Cautelar da Ação de Descumprimento de Preceito Fundamental - ADPF 347 - as aplicações teóricas adotadas na decisão em análise e, por fim, sistematizar dados do Conselho Nacional de Justiça que indicam os direcionamentos para a adoção pelo Judiciário brasileiro da decisão proferida pelo STF na ADPF em estudo, especialmente no que diz respeito às audiências de custódia, à aplicação de medidas alternativas à prisão e encaminhamentos realizados nas Varas de Execução Penal. Para atender aos objetivos propostos a pesquisa desenvolve-se por meio de estudo de caso e análise bibliográfica.

\section{A CONSTRUÇÃO DA FIGURA DO ESTADO DE COISAS INCONSTITUCIONAIS NO JUDICICÁRIO}

O pano de fundo que deu ensejo à construção da figura do estado de coisas inconstitucional, nos países da América Latina, encontra explicação no século 20, quando esses países viveram experiências de ditaduras rigorosas e, posteriormente, ensejaram movimentos que buscavam a restauração da democracia. A questão é que essa reconstrução se realizou por meio da "[...] redireção do constitucionalismo político à reestruturação dos requisitos jurídicos e políticos, abrindo amplo espaço para o reconhecimento de direitos e construção de grandes expectativas sobre o futuro dessas democracias" (GIORGI; VASCONCELOS, 2018, p. 482).

Posteriormente vem o século 21, o qual tem sido uma experiência de frustação para esses países, principalmente no que diz respeito à concretização daquele futuro esperado. Como resposta a tal frustação, tem ocorrido a colonização dos discursos e práticas judiciais orientadas por teorias que legitimam o Direito como 
mecanismo de transformação social. Nesse sentido, a atuação dos tribunais constitucionais vem passando da política para o Direito, esperando que por meio do Direito se operacionalize uma transformação social. Tal momento na história do Direito, em razão desse contexto, tem experimentado uma inflação do protagonismo do Judiciário que se manifesta na forma de ativismo judicial.

A partir desse cenário jurídico o quadro fático de violação de direitos no sistema carcerário brasileiro foi levado ao STF com a expectativa de que uma ação fosse tomada em relação ao estado das penitenciárias brasileiras. Tal ação foi instrumentalizada por meio da ADPF $347,{ }^{1}$ ensejando a qualificação do sistema prisional como um estado de coisas inconstitucional. Essa qualificação/adjetivação traz consequências jurídicas que impõem ao Judiciário a tomada de medidas abrangentes de natureza normativa, administrativa e orçamentária.

No que diz respeito à definição da figura estado de coisas inconstitucional, segundo Lyons, Monterroza e Meza:

La figura del Estado de cosas inconstitucionales puede ser definida como un mecanismo o técnica jurídica creada por la Corte Constitucional, mediante la cual declara que ciertos hechos resultan abiertamente contrarios a la Constitución, por vulnerar de manera masiva derechos y principios consagrados en la misma, en consecuencia insta a las autoridades competentes, para que en el marco de sus funciones y dentro de un término razonable, adopten las medidas necesarias para corregir o superar tal estado de cosas (2011, p. 71).

Insta salientar que a origem deste instrumento jurídico foi cunhada no fim do século 20 em decisões da Corte da Colômbia, na sentença de unificación SU 559 (COLÔMBIA, 1997). Nesta ação se discutia a distribuição especial de educadores e recursos orçamentários relativo à educação. A sentença não declarou a inconstitucionalidade das leis ou dos atos normativos instados, mas, sim, o estado de coisas inconstitucional que violava a Constituição. A partir de tal posição a Corte se auto-outorgou o dever de colaborar com os demais poderes e órgãos do Estado para a realização dos fins que propõe a Constituição colombiana, assim como o de comunicar às autoridades competentes o estado de violação.

A partir do exposto o Tribunal, como responsável pela guarda da Constituição, tomou uma decisão não necessariamente baseada no binômio constitucional/inconstitucional da lei ou ato normativo. Nesse aspecto, o estado de coisas inconstitucional assemelha-se às sentenças ou decisões intermediárias, pois o Tribunal lança mão de um mecanismo diferente dos tradicionalmente previstos na Constituição (OMMATI, 2016, p. 59).

É preciso, no entanto, tecer algumas diferenciações no que diz respeito à declaração do estado de coisas inconstitucional e às sentenças aditivas, pois, enquanto a decisão aditiva nasce em razão de omissão legislativa que força a Corte a proceder ao controle de constitucionalidade no que diz respeito às omissões (REVORIO, 2001, p. 81), a declaração do estado de coisas inconstitucional "[...] se puede definir como un juicio empírico de la realidad, que determina un incumplimiento reiterado y sistemático de la norma constitucional, de tal magnitud, que hace con que la Carta Política quede sin efecto en la praxis" (COLÔMBIA, 2018, p. 2).

A partir de tal definição observa-se que a ação que declara o estado de coisas inconstitucional, para além da concretização dos anseios da carta política, também pretende evitar o excesso de pedidos de tutelas, uma vez que se trata de uma situação de fato que viola um número generalizado de pessoas. Assim sendo, "[...] la declaratoria de estado de cosas inconstitucional pretende garantizar el principio de economía procesal, que consiste en lo siguiente: en el desarrollo del procedimiento se buscará obtener siempre el máximo beneficio, con el menor desgaste del órgano jurisdicional" (RAMÍREZ, 2010, p. 21).

Nesse sentido, pode-se definir que o estado de coisas inconstitucional é um conjunto de atos, ações e omissões, provenientes dos poderes públicos que dão espaço a uma violação maciça de direitos fundamentais. Desse modo, a atividade da Corte ao declarar o estado de coisas inconstitucional acaba por se manifestar para além de uma sentença aditiva ou criativa, materializando-se como uma atividade judiciária ativista, pois se afasta dos mecanismos jurídicos de declaração de constitucionalidade e inconstitucionalidade criados tradicionalmente.

Proposta em 2015 pelo partido político Psol, representado pela Clínica de Direitos Humanos da Universidade Estadual do Rio de Janeiro UERJ - a qual culminou no reconhecimento do estado de coisas inconstitucional do sistema penitenciário Brasileiro (ADPF MC/DF, 2015). 
À vista disso, estudos alertam para o perigo do manuseio de instrumentos criados pelo próprio Judiciário, principalmente em contexto de neoconstitucionalismo e ativismo judicial. Estes apontam que declarar o estado de coisas inconstitucional nada mais representa do que a invasão pelo Judiciário (Direito) sobre as competências do Legislativo (política), ou melhor, há um cancelamento da diferenciação entre Direito/política. Também é destacado que o mecanismo do controle realizado se distingue muito do controle de constitucionalidade do tradicional modelo construído pelo pensamento jurídico, uma vez que este não se dirige à qualificação jurídica de leis ou normas como inconstitucionais, mas a estados de fato (VASCONCELOS, 2017, p. 289-290).

Autores ressaltam o perigo da abrangência e abstração do conceito e requisitos para manuseio de tal instrumento, pois não há procedimento estabelecido, o que inviabiliza avistar limites podendo ensejar ações arbitrárias, principalmente em um país presidencialista, em que "[...] os poderes Executivo e Legislativo vivem às turras e às tensões que tornam o Judiciário cada dia mais forte [...]" (STRECK, 2015).

No entendimento do professor Lênio Streck, o estado de coisas inconstitucional é o auge do ativismo judicial e tal instituto é inviável de ser pensado na prática, principalmente no Brasil, pois se levado a sério o país seria declarado inconstitucional em razão da dissonância do que ele se propõe ser, a partir da Constituição, para o que ele é (STRECK, 2015).

Em contrapartida, há os que sustentam que este é um argumento espantalho, que distorce a visão real sobre o que é o estado de coisas inconstitucional, seus pressupostos e implicações. À vista disso, com base na jurisprudência desenvolvida pela Corte Constitucional da Colômbia, a doutrina tem apontado sinteticamente como sendo três os pressupostos necessários para a caracterização do estado de coisas inconstitucional:

um quadro de violação generalizada, contínua e sistêmica de direitos fundamentais que afeta um número significativo de pessoas;

a prolongada omissão, inércia e/ou incapacidade persistente e reiterada das autoridades públicas em modificar a conjuntura das violações perpetradas para a garantia dos direitos consagrados;

(iii) um conjunto de transgressões inconstitucionais (e inconvencionais) que exigem a atuação não apenas de um único órgão, mas de uma pluralidade de autoridades ("transformações estruturais"), das quais se requer a adoção de um conjunto complexo e coordenado de ações (COLÔMBIA, 2004).

Deste modo, não será qualquer violação de direitos que justificará o manejo da técnica, mas apenas aquela que de forma objetiva se manifestar generalizada, sistemática, estiver relacionada com um estado permanente de inércia estatal e em flagrante incapacidade institucional que aprofunde ou enseje violação generalizada de direitos, pois o manejo de tal instituto pressupõe a ausência de políticas e programas públicos minimamente capazes de superar, gradativamente, o quadro de violação endêmica de direitos humanos (CAMPOS, 2015).

Segundo Konrad Hesse, a Constituição tem a pretensão de eficácia social e de imprimir ordem e conformação à realidade, por isso se diz que ela exerce uma função transformadora na sociedade (HESSE, 1991, p. 15) que, no entanto, é frustrada pela omissão dos entes. Por tais razões, defendem que cabe à doutrina e à jurisprudência o dever de buscar mecanismos que controlem e superem as omissões dos outros poderes, o que pode resultar na necessidade de reanálise dos instrumentos já previstos na Constituição, bem como na necessidade de extração, do próprio ordenamento jurídico, de novas possibilidades para realização desse controle (SOUZA, 2013, p. 102).

\section{ANÁLISE DA PETIÇÃO INICIAL E DA DECISÃO CAUTELAR DA ADPF 347}

Se podes olhar, vê. Se podes ver, repara. (Saramago. Ensaio sobre a cegueira, 1995).

Esta frase foi escrita pelo autor português José Saramago e publicada na contracapa do livro Ensaio sobre a cegueira, em 1995. O interesse da citação é chamar a atenção para a impossibilidade das pessoas de reparar e apreciar as coisas como são. O livro no qual consta a citação retrata o desmoronar completo da sociedade causado pela cegueira branca que aos poucos assolou o mundo.

A partir dessa ilustração, no caso em estudo, a cegueira que acomete o Estado atual é causada pela busca, incessante, por valores de justiça e equidade. Para tanto, juízes trabalham em searas que não lhe foram atribuídas legalmente, fechando os olhos para o Direito e construindo argumentos que são verdadeiras zonas 
de fumaça que não encontram respaldo jurídico; são abertos, arbitrários, e cujos fundamentos justificariam tanto o sim como o não. É esse o contexto de crise que acomete o Estado contemporâneo. Nesse sentido passa-se ao estudo da ADPF $347 \mathrm{com}$ a finalidade de reparar o que de fato acontece.

Inicialmente, volta-se a atenção à inquietação que está no centro do pedido constante na ADPF 347, entre elas há a situação fática de que pessoas vivem em condição desumana em ambiente de superlotação. Tal situação é corroborada em dados ao informar que até junho de 2016 o Brasil contava com uma população cerceada de liberdade de 726.712 (BRASIL, 2016, p. 19) e com um total de 1.422 unidades prisionais, as quais formam 367.217 vagas (BRASIL, 2016, p. 20). Assim, se a população carcerária corresponde a 726.712 pessoas, o déficit de vagas em 2016 era de 359.058 (BRASIL, 2016, p. 21).

Observa-se que ante a situação de déficit de vagas no sistema prisional da Colômbia, o Tribunal interviu aplicando o chamado numerus clausus. Essa não foi uma medida encampada pelo STF, contudo o ministro Lewandowski destacou que o CNJ estava lançando um programa que impõe a necessidade de observar a capacidade prisional de forma taxativa ${ }^{2}$ a ser aplicado pelo Judiciário. Nesse sentido segue o trecho citado:

Concordo também com a medida cautelar do item " $c$ ". Ou seja, aquela que determina aos juízes e tribunais que considerem fundamentadamente o quadro dramático do sistema penitenciário brasileiro, no momento do implemento de cautelares penais na aplicação da pena e durante o processo de execução penal. Eu disse, numa rápida intervenção, no início desta sessão, que a doutrina cogita do chamado numerus clausus no que tange às prisões. Ou seja, as prisões não podem comportar o número maior de presos do que fisicamente podem suportar. Nós estamos lançando, Senhoras Ministras, Senhores Ministros, no CNJ, um novo programa, que é o Programa Cidadania nos Presídios, em que nós adaptamos esta expressão latina para o vernáculo e falamos do princípio da capacidade prisional taxativa. Então, nesse programa, que nós baixaremos por resolução, nós determinamos aos juízes da execução que observem o princípio da capacidade prisional taxativa. Ou seja, não se pode mandar para um estabelecimento prisional mais pessoas do que ele comporta. Portanto, estou plenamente de acordo também com a cautelar do inciso "c" (ADPF MC/DF 347. Supremo Tribunal Federal. Julgamento em 09/09/2015. Ministro Ricardo Lewandowski, p. 179).

Salienta-se que o estado de superlotação das prisões é acompanhado de celas imundas e insalubres que acarretam a proliferação de doenças infectocontagiosas, comida intragável, temperaturas extremas, falta de água potável e de produtos higiênicos básicos. Ressalta-se que esse quadro de violação de direitos, no sistema carcerário brasileiro, faz com que a pessoa sentenciada sofra penas sequer previstas pelo Código Penal, e que a própria Constituição repudia (BRASIL, 2009, p. 172) pois segundo o artigo $5^{\circ}$ (CF/1988) "todos são iguais perante a lei, sem distinção de qualquer natureza, garantindo-se aos brasileiros e aos estrangeiros residentes no País a inviolabilidade do direito à vida, à liberdade, à igualdade, à segurança e à propriedade, nos termos seguintes [...]": III - "[...] ninguém será submetido à tortura nem a tratamento desumano ou degradante [...]". Reforça tal argumento, os incisos do mesmo artigo:

XLVII - não haverá penas:

a) de morte, ${ }^{3}$ salvo em caso de guerra declarada, nos termos do art. $84, \mathrm{XIX}$;

b) de caráter perpétuo;

c) de trabalhos forçados;

d) de banimento;

e) cruéis;

\footnotetext{
O Projeto "Cidadania nos Presídios" é muito mais que uma proposta de atualização de processos. É uma iniciativa do Conselho Nacional de Justiça (CNJ) pelo reconhecimento e pela valorização de direitos, em sentido amplo. Discute-se nova dinâmica e metodologia para o sistema de execução e fiscalização das penas, revendo o funcionamento das Varas de Execução Penal e a superlotação dos presídios, com o reforço da interlocução e interação de todos aqueles que intervêm no processo e nas rotinas da execução penal, têm aptidão para tornar o sistema de justiça "mais humano, aproximando o juiz e a sociedade do jurisdicionado" (Disponível no site: https://www.cnj.jus. br/sistema-carcerario-e-execucao-penal/cidadania-nos-presidios. Acesso em 20/9/2019).

3 A taxa de mortalidade no cárcere em 2016 é de $10 \%$ para os casos de mortes criminais e naturais. Apesar de não ser essa a pena diretamente aplicada pelo Estado, a morte é decorrência de estar a pessoa sob a custódia deste, pois por sua omissão, se viabiliza cenário propício, causada por ação humana ou por doença em razão do estado de insalubridade somado à precariedade do acesso à saúde pela população carcerária (BRASIL, 2016. p. 52).
} 
XLVIII - a pena será cumprida em estabelecimentos distintos, de acordo com a natureza do delito, a idade e o sexo do apenado; ${ }^{4}$

XLIX - é assegurado aos presos o respeito à integridade física e moral;

$\mathrm{L}$ - às presidiárias serão asseguradas condições para que possam permanecer com seus filhos durante o período de amamentação. ${ }^{5}$

O conjunto de informações tecidas anteriormente dimensionam como a situação fática se apresenta dissonante com a Constituição. Tal cenário fez com que a questão fosse judicializada no STF por meio da ADPF 347 proposta em 2015 pelo partido político Psol, ${ }^{6}$ representado pela Clínica de Direitos Humanos da Universidade Estadual do Rio de Janeiro - UERJ.

A partir desse momento o presente estudo volta-se primeiramente para a análise da petição inicial ajuizada pela UERJ e após, o estudo volta a atenção à decisão proferida pelo STF. Assim, iniciando a análise da petição inicial, destaca-se que esta contém alguns pedidos cautelares, entre os quais:

a) Determine a todos os juízes e tribunais que, em cada caso de decretação ou manutenção de prisão provisória, motivem expressamente as razões que impossibilitam a aplicação das medidas cautelares alternativas à privação de liberdade, previstas no art. 319 do Código de Processo Penal.

b) Reconheça a aplicabilidade imediata dos art. 9.3 do Pacto dos Direitos Civis e Políticos e 7.5 da Convenção Interamericana de Direitos Humanos, determinando a todos os juízes e tribunais que passem a realizar audiências de custódia.

c) Determine aos juízes e tribunais brasileiros que passem a considerar fundamentadamente o dramático quadro fático do sistema penitenciário brasileiro no momento de concessão de cautelares penais, na aplicação da pena e durante o processo de execução penal.

d) Reconheça que como a pena é sistematicamente cumprida em condições muito mais severas do que as admitidas pela ordem jurídica, a preservação, na medida do possível, da proporcionalidade e humanidade da sanção, impõe que os juízes brasileiros apliquem, sempre que for viável, penas alternativas à prisão.

e) Afirme que o juízo da execução penal tem o poder-dever de abrandar os requisitos temporais para a fruição de benefícios e direitos do preso, como a progressão de regime, o livramento condicional e a suspensão condicional da pena.

f) Reconheça que o juízo da execução penal tem o poder-dever de abater tempo de prisão da pena a ser cumprida, quando se evidenciar que as condições de efetivo cumprimento da pena foram significativamente mais severas do que as previstas na ordem jurídica e impostas pela sentença condenatória, de forma a preservar, na medida do possível, a proporcionalidade e humanidade da sanção.

g) Determine ao Conselho Nacional de Justiça que coordene um ou mais mutirões carcerários, de modo a viabilizar a pronta revisão de todos os processos de execução penal em curso no país que envolvam a aplicação de pena privativa de liberdade, visando a adequá-los às medidas "e" e " $f$ " anteriores.

h) Imponha o imediato descontingenciamento das verbas existentes no Fundo Penitenciário Nacional Funpen, e vede à União Federal a realização de novos contingenciamentos, até que se reconheça a superação do estado de coisas inconstitucional do sistema prisional brasileiro.

\footnotetext{
${ }^{4}$ Em 2007 garota com 15 anos passou 26 dias presa com 30 homens no Pará na cadeia de Abaetetuba. Folha de São Paulo, 2016. Jeferson Bertolini. Disponível em: https://www1.folha.uol.com.br/cotidiano/2016/11/1828880-garota-que-ficou-presa-com-30-homens-no-para-leva-vida-desprotegida.shtml. Acesso em 25 abr. 2018.

Ressalta-se também que em levantamento do Conselho Nacional do Ministério Público (CNMP) aponta que $68 \%$ entre as 1.598 unidades prisionais do país não separavam os detentos conforme a natureza do delito cometido, como determina a Constituição. Além de unirem, em uma mesma cela, autores de crimes de grande periculosidade com outros de menor gravidade, em $77 \%$ dos estabelecimentos presos primários conviviam com reincidentes. No mesmo período, foram registrados 121 rebeliões e 110 homicídios na cadeia. (O GLOBO. Presídios descumprem lei e não separam detentos por tipo de delito. Karine Rodrigues, 2013. Disponível em: https://oglobo.globo.com/brasil/ presidios-descumprem-lei-nao-separam-detentos-por-tipo-de-delito-10347874. Acesso em: 25 abr. 2019).

5 Apenas $14 \%$ das unidades femininas ou mistas contam com berçário e/ou centro de referência materno-infantil, que compreendem os espaços destinados a bebês com até 2 anos de idade. Apenas $3 \%$ das unidades prisionais do país declararam contar com espaço de creche (BRASIL, 2014, p. 32-33).

6 Partido político Socialismo e Liberdade (PSOL)
} 
Doravante, em uma primeira análise, observa-se que a situação do sistema carcerário brasileiro atual aparenta ter como causa do estado inconstitucional questões políticas, pois diz respeito a um fato resultante da omissão dos poderes, em especial do Executivo e Legislativo, pois esses são os responsáveis por promover a criação de direitos e promoção de estrutura física para concretizá-los. Curiosamente, observa-se que, dos oito pedidos formulados na cautelar, seis reclamam ações direcionadas para o próprio poder Judiciário, ou seja, as medidas propõem um desencarceramento, apontando para a necessidade de racionalizar os excessos que ocorrem nas fases anteriores em que atuam os aplicadores do Direito. Nesse sentido, o ministro Marco Aurélio observa que:

A fundamentação desenvolvida alcança todo o conjunto de pedidos formulados pelo requerente. Entretanto, a apreciação, neste momento, deve-se limitar aos oito pedidos de natureza cautelar: sete versando a interpretação e aplicação da legislação penal e processual penal e um tratando de medida orçamentária da União (ADPF MC/DF 347. Supremo Tribunal Federal. Julgamento em 9/9/2015. Ministro Marco Aurélio, p. 19).

A partir da análise do pedido cautelar, constata-se que $75 \%$ desses se dirigem ao Judiciário. Desse fato é possível depreender que a ADPF em estudo não buscava tão somente o reconhecimento do estado físico de violação de direitos, mas sim a violação na aplicação do próprio direito destas pessoas, na aplicação do Direito e na prática judiciária.

É preciso observar que viabilizar, unicamente, a concretização de condições dignas no cárcere à pessoa esvazia o princípio da legalidade que é pilar do Direito Penal e dispor de verbas para a construção de mais presídios e promover dignidade dentro do cárcere, em um Estado Democrático de Direito, não é o primeiro fazer cabível, mas sim o de observar a legalidade das prisões dos atuais 716 mil presos que compõem o sistema carcerário brasileiro, para após viabilizar condições de dignidade dentre do cárcere.

A reflexão trazida anteriormente deu-se em razão de se perceber, na decisão cautelar, que há responsabilidade do poder Judiciário no estado de coisas inconstitucional dos cárceres brasileiros, justamente em razão do excesso de prisões provisórias que corresponde a $41 \%$ da população carcerária. 0 dado mais importante a ser observado é que segundo pesquisa, a maioria dos que estão sob prisão provisória alcançam absolvição ou são condenados a penas alternativas. $O$ relator da ação diz que esse fato corrobora a existência da chamada cultura do encarceramento no Judiciário brasileiro (BRASÍLIA, 2015, p. 28).

Voltando-se a atenção do estudo à decisão cautelar proferida pelo STF, esta baseou-se em dados estatísticos trazidos pelo Infopen, questões sociológicas, históricas e por fim indicaram ser a raiz do encarceramento em massa uma questão estrutural e sistêmica que envolvem os poderes da União.

Nesse sentido, o relator ressalta que a responsabilidade pelo estágio ao qual chegou o sistema carcerário não pode ser atribuída a um único poder, mas sim aos três - Legislativo, Executivo e Judiciário - pois há problemas tanto de formulação e instituição de políticas públicas quanto de interpretação e aplicação da lei penal. Assim, a falta de coordenação institucional causou o quadro de violação generalizada e contínua dos direitos fundamentais dos presos, o que diariamente continua sendo agravado em razão de ações, omissões e falhas estruturais que decorrem dos três poderes (BRASÍLIA, 2015, p. 27-28).

Diante desse estado sistêmico de violação de direitos, segundo o relator, o papel do Tribunal é tomar decisões, primariamente políticas, sem afrontar o princípio democrático e da separação de poderes. Nesse sentido, entende que é necessária a superação de bloqueios políticos e institucionais que vêm impedindo o avanço de soluções, o que significa que "[...] cabe ao Tribunal o papel de retirar os demais poderes da inércia, catalisar o debate e novas políticas públicas, coordenar as ações e monitorar os resultados [...]" (BRASíLIA, 2015, p. 31).

Outro argumento ressaltado pelo relator diz respeito ao déficit na representação das pessoas encarceradas, o que acaba por fomentar a inação por parte dos poderes, principalmente do Executivo e Legislativo em razão da desaprovação da população. Isso posto, diante da impossibilidade de debater o problema do cárcere no campo político, é legítimo ao Supremo Tribunal Federal o papel de coordenar a interação interinstitucional 
necessária à correção das falhas estruturais que jamais teriam decorrido de um único agente, órgão ou ente, mas de uma indeterminável multiplicidade de atos (BRASíLIA, 2015, p. 31-32). Nesse sentido, a decisão do STF toma contornos políticos e envolto nesses argumentos, deferiu parcialmente os pedidos cautelares. ${ }^{7}$

A posição do relator não foi seguida integralmente no voto final da Corte, a qual, por maioria, deferiu a cautelar em relação à alínea "b", determinando aos juízes e tribunais que, observados os artigos 9.3 do Pacto dos Direitos Civis e Políticos e 7.5 da Convenção Interamericana de Direitos Humanos, realizem, em até 90 dias, audiências de custódia, viabilizando o comparecimento do preso perante a autoridade judiciária no prazo máximo de 24 horas, contadas do momento da prisão. Em relação à alínea " $h$ ", por maioria e nos termos do voto do relator, também foi deferida para determinar à União que libere o saldo acumulado do Fundo Penitenciário Nacional para utilização e abstendo-se de realizar novos contingenciamentos. As alíneas "a", "c", "d", "e" e "f" foram indeferidas pela maioria e a alínea "g" foi prejudicada (BRASÍLIA, 2015, p. 209-210).

Diante do conjunto de pedidos e das decisões que compõem a ADPF 347, o que se extrai, primeiramente, dos pedidos feitos é que seis reclamavam medidas direcionadas ao Judiciário. Destes seis pedidos, contudo, um foi acolhido, qual seja, o que diz respeito às audiências de custódia. É importante ressaltar que dois pedidos cautelares são dirigidos a outros poderes e órgãos do Estado e entre eles a alínea " $\mathrm{h}$ " é deferida determinando o descontingenciamento orçamentário para investimentos no setor prisional.

Apesar de um dos seis pedidos dirigidos ao Judiciário serem deferidos, os ministros ressaltaram em seus votos a responsabilidade do Judiciário no quadro de atual inconstitucionalidade. Corrobora o exposto o trecho colacionado a seguir:

A situação de penúria do sistema prisional do país é tão notória, o que quer se diga, será expletivo e, claro, vergonhoso para todos nós. E como tenho destacado, nós não temos, no âmbito do Judiciário, sequer a desculpa de dizer que isso é culpa da Administração, porque somos administradores do sistema. Como destacou há pouco o ministro Celso, temos grande responsabilidade na mantença desse quadro caótico. (ADPF MC/DF 347. Supremo Tribunal Federal. Julgamento em 09/09/2015. Ministro Gilmar Mendes, p. 135-136).

Com fundamento no exposto, percebe-se que a decisão do STF criou uma fumaça branca ao atender majoritariamente pedidos dirigidos a outros órgãos e poderes externos ao Judiciário, apesar de reconhecer que o problema se mantém em razão de generalizada ilegalidade que se repete nas operações no sistema do Direito.

Nesse sentido, atender majoritariamente pedidos que têm aplicação externa ao Judiciário funcionou como manobra argumentativa que dá a aparência de que o problema está no interior da política e muito longe do Judiciário, mas tanto os pedidos como a decisão evidenciam que o argumento é fantasioso, pois $75 \%$ dos pedidos cautelares são dirigidos ao Judiciário e $25 \%$ exigem que o STF determine a outros órgãos e poderes da União ações para dirimir o estado de inconstitucionalidade. Apesar, contudo, de a maioria dos pedidos serem dirigidos ao Judiciário, apenas $10 \%$ deles são atendidos pelo STF, enquanto, no que diz respeito aos pedidos dirigidos a outros órgãos o percentual de procedência é de $50 \%$.

\footnotetext{
7 Ante o exposto, defiro, parcialmente, a medida liminar requerida, determinando:

a) aos juízes e tribunais - que lancem, em casos de determinação ou manutenção de prisão provisória, a motivação expressa pela qual não aplicam medidas cautelares alternativas à privação de liberdade, estabelecidas no artigo 319 do Código de Processo Penal;

b) aos juízes e tribunais - que, observados os artigos 9.3 do Pacto dos Direitos Civis e Políticos e 7.5 da Convenção Interamericana de Direitos Humanos, realizem, em até 90 dias, audiências de custódia, viabilizando o comparecimento do preso perante a autoridade judiciária no prazo máximo de 24 horas, contadas do momento da prisão;

c) aos juízes e tribunais - que considerem, fundamentadamente, o quadro dramático do sistema penitenciário brasileiro no momento de concessão de cautelares penais, na aplicação da pena e durante o processo de execução penal;

d) aos juízes - que estabeleçam, quando possível, penas alternativas à prisão, ante a circunstância de a reclusão ser sistematicamente cumprida em condições muito mais severas do que as admitidas pelo arcabouço normativo;

e) à União - que libere o saldo acumulado do Fundo Penitenciário Nacional para utilização com a finalidade para a qual foi criado, abstendo-se de realizar novos contingenciamentos.

É como voto (ADPF 347, 2015, p. 41-42).
} 
A partir de tal análise o que se verifica é a inversão de argumentos, pois o problema mostra-se aprofundado no interior da aplicação do Direito, o que é corroborado nos pedidos da cautelar, entre eles o que reclama ao STF a determinação aos juízes que fundamentem quando não aplicarem medidas alternativas à prisão provisória. É importante ressaltar que esse pedido foi afastado/prejudicado, sob a justificativa de que tal questão já é determinada em lei. Como forma de ilustrar o exposto segue trecho da decisão:

Indefiro os pedidos dos itens c, d, e e f. Inócuo se me afigura o que neles pretendido, presentes os termos da legislação em vigor, em que a privação de liberdade como pena definitiva é exceção (quando não substituída por penas restritivas de direito) e só cabe a prisão preventiva quando não substituível por outra medida cautelar - art. 282, §6으, do CPP, antes transcrito (ADPF MC/DF 347. Supremo Tribunal Federal. Julgamento em 09/09/2015. Ministra Rosa Weber, p. 108).

Tal posicionamento contradiz argumentos tecidos anteriormente na decisão ao reconhecer presente a cultura do encarceramento no sistema Judiciário, o que obstaculiza a aplicação da lei, pois tão somente a determinação legal não é capaz de trazer concretude ao direito (BRASílIA, 2015, p. 11).

Observa-se que a cultura do encarceramento é evidenciada no fato de que a aplicação de pena provisória em excesso ou ilegal não vem sendo corrigida e identificada na via recursal e apesar de as audiências de custódia estarem expressas em tratado e pacto internacionais, dos quais o Brasil é signatário, estas não foram regularmente postas em prática.

Salienta-se que apesar de a Corte entender necessária a adoção de determinadas providências, o Judiciário não as adota por entender que a procedência de pedidos dirigidos ao Judiciário poderia causar a expansão de ações de reclamações no STF.

Analiso as medidas requeridas: As alíneas "a", "c" e "d" são conexas, pelo que as analiso em conjunto. Determinação aos juízes e tribunais que lancem, em casos de determinação ou manutenção de prisão provisória, a motivação expressa pela qual não aplicam medidas cautelares alternativas à privação de liberdade, estabelecidas no artigo 319 do Código de Processo Penal. O relator deferiu essas medidas endereçadas diretamente a juízes e tribunais. Tenho que, na linha do que defendido pelo ministro Edson Fachin, não há dúvida de que os juízes já devem considerar a situação prisional ao expedir ordens de prisão. Como reforço ou incentivo, a medida até poderia ser positiva. No entanto, a exigência de motivação escrita nas decisões acerca da situação carcerária representaria mais um capítulo nas decisões judiciais. Em muitos casos, seria um capítulo genérico, sem efetivo cotejo da situação com o caso concreto. Daí, adviria o aumento do número de reclamações que o Supremo Tribunal Federal receberá - ou receberia - sem contar que prisões necessárias acabariam desconstituídas por falha do magistrado em acrescentar considerações formais à decisão. Para reduzir a cultura do encarceramento, talvez fosse mais recomendável atuar no campo da formação, conscientizando os magistrados acerca do estado de coisas e de suas consequências. A Enfam, a Escola Nacional de Formação e Aperfeiçoamento de Magistrados, pode ser chamada a protagonizar essa transformação, oferecendo treinamentos que contemplem a situação prisional e as medidas alternativas ao encarceramento. Por ora, não proporia a medida como ordem, mas pura sugestão ou recomendação. Assim, acompanho a divergência e indefiro a medida cautelar às alíneas "a", "c" e "d". Proponho a expedição de ofício à Enfam, recomendando a elaboração de plano de trabalho para oferecer treinamento a juízes sobre o sistema prisional e medidas alternativas. (ADPF MC/DF 347. Supremo Tribunal Federal. Julgamento em 09/09/2015. Ministro Gilmar Mendes, p. 138).

Continuando o estudo observa-se que a mesma Corte decidiu, permeada pela ponderação de princípios e mecanismos da sentença aditiva, ser constitucional a aplicação de prisão sem trânsito em julgado, ${ }^{8}$ ressaltando-se que isso se deu um ano após ter declarado o estado de coisas inconstitucional do sistema carcerário. Tal decisão deixa transparecer uma incongruência quanto à posição institucional da Corte.

Por fim, com respaldo em todo o exposto, observa-se que somente juízes podem restringir a liberdade humana. Segundo o artigo 50 da Constituição, incisos LIV "ninguém será privado da liberdade ou de seus bens sem o devido processo legal [...]"; " LVII - ninguém será considerado culpado até o trânsito em julgado de sentença penal condenatória[...]"; "LXI - ninguém será preso senão em flagrante delito ou por ordem escrita e

\footnotetext{
Por maioria, o Plenário do Supremo Tribunal Federal (STF) entendeu que o artigo 283 do Código de Processo Penal (CPP)* não impede o início da execução da pena após condenação em segunda instância e indeferiu liminares pleiteadas nas Ações Declaratórias de Constitucionalidade (ADCs) 43 e 44 (BRASÍLIA, 2016a,b).
} 
fundamentada de autoridade judiciária competente [...]", ou seja, somente se encarcera por meio da chancela do Judiciário (BRASIL, 1988) que se concretiza por meio do processo de criminalização, o qual se iniciou com a atividade legislativa que faz nascer o crime. Após a atividade policial e atuação dos aplicadores do Direito, se legitima todo processo anterior pelo juiz (ZAFFARONI, 2011, p . 69).

Nesse sentido, o que se percebe é que a superlotação, a tortura e a violência são resultado da história, de crises, das omissões e excessos dos poderes da União, mas a produção dessas violências são mantidas, em especial no interior das relações jurídicas concretas e observáveis, pois toda vez que não ocorre inspeção judicial no interior das penitenciárias ou não as detecta é dessa omissão que se permite que o estado de tortura e violência se instale. É de todo decreto de prisão que não atentou para a possibilidade de aplicar uma pena alternativa, que se produz o encarceramento sem uma pena definitiva. É de toda vez que se negou a liberdade diante de conhecidas e notórias violação de Direitos que nasce o encarceramento em massa (GIORGI; VASCONCELOS, 2018, p. 490).

\section{ANÁLISE DE DADOS E ENCAMINHAMENTOS DO JUDICIÁRIO APÓS A ADPF 347/STF}

Após os argumentos tecidos anteriormente, o presente artigo volta-se a analisar o estabelecimento, no Judiciário, das determinações cautelares proferidas pelo STF na MC/DF ADPF 347 e a atividade do Judiciário brasileiro, no âmbito penal, após o reconhecimento do estado de coisas inconstitucional.

Para tanto, foi necessário o estudo dos dados levantados pelo Conselho Nacional de Justiça (CNJ), sob a presidência da ministra Carmem Lucia. A finalidade é complementar o estudo, verificando como está sendo posta em prática a decisão cautelar no que diz respeito às medidas direcionadas ao Judiciário, bem como verificar como a atividade judicial da magistratura brasileira, no âmbito penal, vem se direcionando após o reconhecimento do estado de coisas inconstitucional.

Com a finalidade de organizar o estudo, proceder-se-á à divisão deste item em dois subitens, os quais analisarão os encaminhamentos que o Judiciário procedeu para o cumprimento da decisão do STF tendo como foco as Varas de Execuções Penais no Brasil; a instituição das audiências de custódia no Brasil até 2017; em atenção à resolução do CNJ, ao artigo 9.3 do Pacto dos Direitos Civis e Políticos e artigo 7.5 da Convenção Interamericana de Direitos Humanos, bem como verificar se os juízes e tribunais estão dando preferência à aplicação de medidas cautelares e alternativas à privação de liberdade conforme o artigo 319 do Código de Processo Penal.

\subsection{A Instituição das Audiências de Custódia no Brasil até 2017: Alínea "b" da Decisão Cautelar da ADPF 347 e os Presos Sem Condenação}

Conforme analisado no decorrer do trabalho, uma das medidas que o STF determinou ao Judiciário brasileiro foi a necessidade de se realizar audiências de custódia no país. Em cumprimento ao exposto, o CNJ as regulamentou pela Resolução no 213/2015, a qual vem sendo objeto de diversos estudos e pesquisas.

Com a finalidade de compreender a instauração de tal medida destaca-se que o CNJ procedeu relatório sistematizado com informações que compilavam os principais dados extraídas do banco de dados do Sistac Sistema de Audiências de Custódia - com vistas a compreender o grau de expansão do instituto às Comarcas do interior, bem como de detectar o número de Comarcas em que houve registro de audiências de custódia no ano de 2017 e em quais delas nenhuma audiência foi realizada (BRASIL, 2017, p. 5-6).

Com base nos dados, o número de Comarcas no Brasil compreende um total de 2.885. Destas, 1.019 estão realizando audiências de custódia, o que corresponde a 35,3\%. Por outro lado, observa-se que 1.866, até 2017, não estavam realizando audiências de custódia, o que perfaz o percentual de $64,68 \%$. Das Comarcas que estão realizando audiências de custódia, 75 realizaram audiências aos finais de semana, 292 realizam a audiência em até 48 horas da prisão e, conforme dados do CNJ, no ano de 2017 foram realizadas 161.409 audiências de custódia (BRASIL, 2017, p. 7).

Com o intuito de se aferir a aplicação do instituto em estudo, deve ser estabelecida a relação entre o número total de prisões e o número de audiências de apresentação. Com base nas últimas edições do relatório Infopen, o número de entradas no semestre analisado gira em torno de 250 novos presos no sistema, o que permite considerar que a cada ano ingressam no país de $60 \%$ a $80 \%$ novos presos em relação ao número 
total de presos (BRASIL, 2017, p. 10-11). Tendo em vista tais dados, o CNJ firmou percentual do número de audiências de custódia realizadas em relação ao número total de pessoas privadas de liberdade no ano de 2017 em 665.595 pessoas e foram realizadas 161.424 audiências de custódia, o que equivale ao percentual de 4,12 (BRASIL, 2017, p. 11).

No que respeita à abrangência da execução das audiências de custódia no Brasil, de um total de 2.885 Comarcas analisadas, registrou-se, no ano de 2017, ao menos uma audiência de custódia em 1.019 Comarcas, o que equivale a $35,3 \%$ do universo analisado (BRASIL, 2017, p. 8).

Quanto ao número de presos provisórios, os quais estão sem condenação, o percentual ultrapassa $50 \%$ do total em nove Estados brasileiros. A média nacional é de $40 \%$, de presos provisórios sem condenação, que se mantém nos últimos anos. Observa-se que apesar da modificação do CPP, artigo 319, e da resolução do CNJ que regulamenta as cautelares e as audiências de custódia, há um total de $24,72 \%$ de presos condenados em execução provisória, 35,15\% de presos condenados em execução (BRASIL, 2018, p. 44).

No que diz respeito ao tipo de regime aplicado aos presos, segundo dados do CNJ, 74,09\% estão em regime fechado, 24,13\% em regime semiaberto e 1,76\% estão em regime aberto (BRASIL, 2018, p, 44-45).

Dados apontam que houve um crescimento do percentual de presos provisórios no período de dezembro de 2015 a junho de 2016 no Distrito Federal, que passou de 21,3\% para 24\%; na Paraíba, que passou de 39,9\% para 42\%; no Rio Grande do Sul, que passou de 34,5\% para 38\%; em Santa Catarina, que de 23,6\% passou para 36\%; em São Paulo, que de $29,2 \%$ passou para $32 \%$ e em Tocantins, que de $37,8 \%$ passou para $39 \%$. Estes dados colocam em questão a efetividade da Lei das Cautelares e das audiências de custódia para o objetivo de redução do número de presos provisórios no País (BRASIL, 2018, p. 48).

Dados gerais disponibilizados pelo CNJ, atualizados até o mês de abril de 2017, informam que o total de audiências de custódia realizadas foram de 229.634, destas, 103.669 (45,15\%) resultaram em liberdade e 125.965 (54,85\%) resultaram em prisão preventiva. Em 11.051 (4,81\%) houve alegação de violência no ato da prisão e em 24.721 (10,77\%) ocorreu encaminhamento social/assistencial (BRASIL, 2018, p, 48).

O uso em excesso de prisão provisória foi um dos temas discutidos pelos ministros em seus votos e, por estes foi pautada a necessidade de a magistratura brasileira observar a aplicação de medidas alternativas à privação de liberdade aos presos provisórios sem condenação. Assim, apesar de se tratar de um pedido cautelar indeferido, este compôs os debates no STF que direcionaram medidas à redução do estado de coisas inconstitucionais. Nesse sentido seguem-se alguns trechos dos votos de cada ministro para ilustrar o exposto.

Como se sabe, a prisão provisória, que deveria ser excepcional, virou a regra, ficando os indivíduos meses ou anos detidos, provisoriamente, sem exame adequado das razões da prisão. Banaliza-se o instituto, olvida-se o princípio constitucional da não culpabilidade (artigo 5ㅇ, inciso LVII) e contribui-se para o problema da superlotação carcerária. Tenho como adequado o pedido (ADPF MC/DF 347. Supremo Tribunal Federal. Julgamento em 09/09/2015. Ministro Marco Aurélio, p. 19-20).

Veja Vossa Excelência: nós nos deparamos diuturnamente, nas Turmas, com prisões sem fundamentação, prisões mal decretadas e todas essas perplexidades que foram narradas na ação de descumprimento de preceito fundamental. Então, o fato de haver uma lei que obriga o juiz a motivar, que o obriga a proceder dessa maneira, não esvazia a ação de descumprimento de preceito fundamental; pelo contrário, nós estamos reconhecendo esse "estado de coisas inconstitucional", exatamente porque os juízes não motivam, eles não fundamentam as suas prisões (ADPF MC/DF 347. Supremo Tribunal Federal. Julgamento em 09/09/2015. Ministro Luiz Fux, p. 113-116).

Por tudo, presidente, essa arguição de preceito fundamental cumpre - como diz o Ministro Fux - um papel fundamentalíssimo que compete ao Supremo discutir. O ministro Gilmar Mendes tem repetido, algumas dezenas de vezes, que este é um problema nosso, porque o Judiciário manda prender, o Judiciário manda soltar, o Judiciário tem a obrigação de fiscalizar, e o Judiciário é o responsável da pessoa sob a sua guarda. Portanto, é preciso haver uma grande transformação. Não sei como isso se faz, sei apenas que não há milagre a ser feito nessa área - e eu não faço milagre, faço Direito (ADPF MC/DF 347. Supremo Tribunal Federal. Julgamento em 09/09/2015. Ministro Cármem Lúcia, p. 126).

Na Turma, temos feito essa observação, a despeito de todo o novo aparato do artigo 319, do Código de Processo Penal, os juízes sequer prestam atenção a essa disposição e, talvez, um pouco por conta da cultura da prisão provisória que precisa de ser modificada (ADPF MC/DF 347. Supremo Tribunal Federal. Julgamento em 09/09/2015. Ministro Gilmar Mendes, p. 126). 
Acompanho Sua Excelência o relator, entendendo, inicialmente, que é perfeitamente válido, data venia, acoIher a cautelar solicitada no item "a", determinando-se aos juízes que lancem uma argumentação mais sólida relativamente à manutenção da prisão provisória, explicitando por que não adota as medidas cautelares. Até porque o art. 312 foi modificado pela Lei 12.403/2011, ou seja, há muito tempo já, e os juízes vêm procedendo como se essa alteração não tivesse existido, determinando prisões provisórias em termos abstratos, com base no art. 312 de nossa Carta Magna. Trata-se, como disse o ministro Luiz Fux, de uma medida pedagógica importante de caráter didático, que deve ser mantida (ADPF MC/DF 347. Supremo Tribunal Federal. Julgamento em 09/09/2015. Ministro Ricardo Lewandowski, p. 178).

Ante os trechos colacionados, é possível constatar que o STF detectou como uma das causas do estado inconstitucional das prisões a ação do Judiciário no excesso de aplicação de prisões provisórias. O STF, contudo, optou por não dirigir ações capazes de catalisar o debate e reduzir o estado de violação a este órgão, mas voltou seus esforços a outros órgãos, o que reforça que o enfrentamento das questões se deu de forma fantasiosa, pois desviou a atenção do que de fato é causa.

Por fim, considera-se que apesar dos dados do Infopen, CNJ e das discussões no STF quanto ao estado de coisas inconstitucional, há ainda a necessidade de mudanças para que se atenue tal violação no sistema penitenciário brasileiro. Quanto aos encaminhamentos dados pelo STF ao Judiciário, destaca-se que estes foram tímidos. Assim, é necessário a intensificação de esforços no sentido de efetivação plena do instituto da audiência de custódia, bem como na redução de presos provisórios.

\subsection{Um Estudo nas Varas de Execução Penal}

c) Determine aos juízes e tribunais brasileiros que passem a considerar fundamentadamente o dramático quadro fático do sistema penitenciário brasileiro no momento de concessão de cautelares penais, na aplicação da pena e durante o processo de execução penal.

e) Afirme que o juízo da execução penal tem o poder-dever de abrandar os requisitos temporais para a fruição de benefícios e direitos do preso, como a progressão de regime, o livramento condicional e a suspensão condicional da pena.

f) Reconheça que o juízo da execução penal tem o poder-dever de abater tempo de prisão da pena a ser cumprida, quando se evidenciar que as condições de efetivo cumprimento da pena foram significativamente mais severas do que as previstas na ordem jurídica e impostas pela sentença condenatória, de forma a preservar, na medida do possível, a proporcionalidade e humanidade da sanção (Plenário - MC/DF ADPF 347, julgamento 09/09/2015, p. 9-10).

Neste momento, o estudo dirige-se às Varas de Execução Penal. A finalidade é verificar a atividade judicial após a declaração do estado de coisas inconstitucional. Observa-se que é necessário dar ênfase a essa área do Direito porque cabe às varas de execução penal fiscalizar a legalidade das medidas penais aplicadas à população carcerária, bem como dar seguimento à ação executando a pena. Por essas razões, a petição inicial da ADPF 347 direcionou medidas judiciais aos juízes da execução penal, contudo tais pedidos foram indeferidos pelo STF (BRASÍLIA, 2015, p. 209-210).

Vistos, relatados e discutidos estes autos, acordam os Ministros do Supremo Tribunal Federal em, apreciando os pedidos de medida cautelar formulados na inicial, por maioria em (...) indeferir as cautelares em relação às alíneas "a", "c" e "d", vencidos os Ministros Relator, Luiz Fux, Cármen Lúcia e o Presidente, que as deferiam; em indeferir em relação à alínea "e", vencido, em menor extensão, o Ministro Gilmar Mendes; e, por unanimidade, em indeferir a cautelar em relação à alínea "f"; em relação à alínea "g", por maioria e nos termos do voto do Relator, o Tribunal julgou prejudicada a cautelar, vencidos os Ministros Edson Fachin, Roberto Barroso, Gilmar Mendes e Celso de Mello, que a deferiam nos termos de seus votos (BRASílIA, 2015, p. 4).

Destaca-se que o objetivo precípuo deste item é perscrutar os encaminhamentos realizados pela magistratura brasileira, especificamente nas Varas de Execução Penal, a partir de dados levantado pelo CNJ. Para tanto, se aferiu quais os padrões organizacionais das unidades jurisdicionais como competência à execução o penal no Brasil, a quantidade de Varas e juízes, verificar os tipos de execução em tramitação no Brasil até 2017 e por fim detectar os regimes adotados nas sentenças do ano de 2017. 
Salienta-se que este levantamento representa um recorte que viabiliza se aprofundar a partir de uma questão, uma vez que se refere unicamente às Varas de competência de execução penal. Conforme dados, foram verificadas a existência de 132 Varas com competência exclusiva, 939 Varas com competência cumulativa e 1.027 Varas únicas, que entre suas atribuições estão incluídas àquelas relativas à execução penal. Assim, a quantidade de Varas que realizam execução penal no país corresponde a 2.098 (BRASIL, 2017, p. 10, 25).

Voltando a atenção às 132 Varas de competência exclusiva em execução penal no Brasil, dados apontam que nestas há um total de 195 juízes. Deste total, 38 acumulam atividades na Vara de Execução com outras tarefas. Assim, o percentual de juiz por Vara é de 1,49 (BRASIL, 2017, p. 14).

Quanto ao número de processos distribuídos e em tramitação por tipo de execução observa-se que no ano de 2015 havia 332.593 processos distribuídos para execução sob o tipo de prisão em privativa de liberdade, o que representa $81 \%$ dos processos distribuídos no ano referente. Em 2016 houve 306.000 processos distribuídos para execução sob a forma de privação de liberdade, o que continua a representar o percentual de $81 \%$ dos processos distribuídos no ano referente (BRASIL, 2017, p. 15).

Quanto ao número de processos de execução penal distribuídos em 2015 em que não havia privação de liberdade houve 79.906, o que corresponde a 19\% dos processos distribuídos. Em 2016 o número de processos em execução penal, em que não havia privação de liberdade, era de 71.810 o que representa 19\%, ou seja, os percentuais se mantiveram de um ano para ao outro (BRASIL, 2017, p. 15-16).

No ano de 2017, segundo dados do CNJ, havia 537.915 pessoas sentenciadas. Seguindo a análise dos dados, contudo, a partir da perspectiva do regime adotado às pessoas, o número de sentenciados no regime fechado foi de 268.822, no semiaberto 128.581 , na prisão domiciliar sem monitoramento eletrônico 84.095, no livramento condicional 26.545, na casa de albergado sem monitoramento eletrônico 22.958 e com monitoramento eletrônico 1.284 (BRASIL, 2017, p. 20).

Observa-se que outra medida discutida pelo STF na decisão cautelar em estudo diz respeito à necessidade de realização de mutirões com a finalidade de aferir possibilidade de comutação de pena, aplicabilidade de indultos e verificação nos processos se havia pessoas que já cumpriram a pena, mas ainda continuavam no cárcere.

Nesse sentido, segundo o CNJ, das Varas de Execução Penal analisadas, 102 não realizaram mutirão de indulto ou comutação de pena, o que corresponde a 78\% das Varas estudadas, e 29 realizaram, o que corresponde a $22 \%$. Entre as pessoas que foram beneficiadas com indulto ou comutação de pena, $55 \%$ foram alcançadas pelo instituto do indulto e $42 \%$ com comutação de pena (BRASIL, 2017, p. 21-22).

Caminhando para o fim da demonstração de dados sistematizados pelo CNJ no campo das Varas Execução Penal no Brasil, é importante salientar que com base nos dados, observa-se que para a instituição e cumprimento da decisão cautelar na ADFP 347 é preciso observar que a realidade da execução penal no Brasil impõe obstáculos que precisam ser sanados. É exemplo do exposto a disparidade de número de processo por juiz, pois cada magistrado da execução penal, em média, é responsável por 4.397 processos (BRASIL, 2017, p. 25).

Há, contudo, variações do número de processos por juiz, que por vezes se mostra desigual. Por exemplo, existem Varas em que 4 juízes acompanham 48.089 processos, o que representa cerca de 12.022 processos por juiz. Há outras Varas em que 2 juízes são responsáveis por 4.877 processos, o que representa cerca de 2.438 processos por juiz, ou, ainda, há Varas nas quais juízes cuidam de 27.135 processos (BRASIL, 2017, p. 25).

Por fim observa-se que o cenário brasileiro no âmbito da execução penal tem 717 estabelecimentos penais sob a supervisão das 132 Varas. Esses estabelecimentos estão sendo acompanhados 629.733 presos, dos quais 599.841 são homens e 29.892 são mulheres. Vale observar que o número de estabelecimentos penais por Vara também varia consideravelmente. Embora em média haja cinco estabelecimentos penais por Vara, nos dados do CNJ há registro de Vara responsável por 50 estabelecimentos penais e há outras responsáveis por 1 ou nenhum estabelecimento penal (BRASIL, 2017, p. 26).

Nesse contexto, com base no cenário apresentado pelos dados, há situações que podem dificultar a prática pelo Judiciário das direções dadas pelo STF na ADPF 347 para amenizar o estado de coisas inconstitucionais reconhecido pelo Supremo. 


\section{CONCLUSÃO}

Os dados colacionados no decorrer do trabalho indicam que o problema central no cárcere é o estado de superlotação, pois deste decorre toda ineficiência na concretização de direitos mínimos. A pesquisa demonstra que a manutenção e aprofundamento de violações nascem daqueles que os chancelam, que fazem uso arbitrário da prisão provisória, que criam argumentos jurídicos, a partir da ponderação de princípios, para legitimar o encarceramento antes do trânsito em julgado, o que inclusive está em contrariedade com previsão expressa na Constituição.

À vista disso, se extrai que no Direito na contemporaneidade abandonou o modelo de legislador negativo, passando a atuar como principal protagonista na produção de efeitos positivos sobre a realidade social. O neoconstitucionalismo foi politizando e transformando o papel dos juízes, os quais passaram a ter legitimidade e ser corresponsáveis, para além do dizer o Direito, por fazer construções que não nascem da tradicional atuação que recaía ao Judiciário.

Por fim, percebe-se que o instrumento jurídico criado "estado de coisas inconstitucional" foi usado no caso em tela como desvio argumentativo, uma vez que as organizações do Direito são as primeiras a produzir o estado de inconstitucionalidade e apesar do exposto, poucas ações foram dirigidas a atender essa questão, que apenas demandaria ações voltas a sua própria estrutura.

Também destaca-se que a análise de dados demonstra que o Judiciário se mantém fazendo uso exacerbado de prisões provisórias de pessoas sem condenação, bem como encontra dificuldades práticas para proceder à fiscalização mais eficiente no cumprimento de pena na fase de execução.

Ressalta-se que o STF apontou que o estado de coisas inconstitucional decorre de construções históricas, sociológicas e políticas, bem como de ações e não ações dos três poderes, contudo, apesar de este ter detectado o excesso de prisões provisórias aplicadas pelo Judiciário, o STF designou vários encaminhamentos aos outros poderes e apenas determinou a prática das audiências de custodia ao Judiciário.

Apesar da importância da medida determinada, no que diz respeito às audiências de custódia, o presente estudo permitiu-nos concluir que o estado de coisas inconstitucional nasce do estado de superlotação. $\mathrm{E}$ a existência do estado de superlotação nos cárceres brasileiros mantém-se em razão da aplicação do Direito, do dizer o Direito dessas pessoas, especialmente em razão da aplicação de encarceramento a presos provisórios não condenados.

Por tais razões, ainda que haja maiores investimentos e criação, pelo Legislativo, de leis com medidas alternativas ao encarceramento, se o Judiciário mantiver a aplicação de excessos nas prisões, manter-se-á o "status quo". Isso posto, é necessário que o protagonista em legitimar o estado de encarceramento observe a racionalidade legal, sujeitando-se à contenção legal.

\section{REFERÊNCIAS}

BRASIL. Congresso Nacional. Comissão Parlamentar de Inquérito do Sistema Carcerário. Editora Biblioteca Digital da Câmara dos Deputados. 2009. p. 620. Disponível em: http://bd.camara.leg.br/bd/handle/bdcamara/2701. Acesso em: 10 set. 2018.

BRASIL. Pacto Internacional sobre Direitos Civis e Políticos. Promulgado pelo decreto n592, de 6 de julho de 1992 . Disponível em: http://www.planalto.gov.br/ccivil_03/decreto/1990-1994/d0592.htm. Acesso em: 12 dez. 2018.

BRASIL. Brasília. Levantamento Nacional de Informações Penitenciárias. Depen. Jun. 2016. Ministério da Justiça e Segurança Pública Departamento Penitenciário Nacional - Depen. Disponível em: http://depen.gov.br/DEPEN/noticias-1/noticias/infopen-levantamento-nacional-de-informacoes-penitenciarias-2016/relatorio_2016_22111.pdf. Acesso em: 12 out. 2018.

BRASIL. Infopen Mulheres. Levantamento nacional de informações penitenciárias. Ministério da Justiça e Segurança Pública. Departamento Penitenciário Nacional - Depen. Junho de 2014. Disponível em: http://www.justica.gov.br/news/estudo-traca-perfil-da-populacao-penitenciaria-feminina-no-brasil/relatorio-infopen-mulheres.pdf. Acesso em: 10 jul. 2018.

BRASIL. Constituição da República Federativa do Brasil. 1988. Disponível em: http://www.planalto.gov.br/ccivil_03/Constituicao/Constituicao.htm. Acesso em: 11 nov. 2018.

BRASIL. Relatório de expansão das audiências de custódia no ano de 2017. p. 294. Conselho Nacional de Justiça - CNJ. Disponível em: http://www.cnj.jus.br/files/conteudo/arquivo/2018/09/2178b9a11524106a0d04ea673839242a.pdf. Acesso em: 27 set. 2019. 
BRASIL. Relatório analítico propositivo - políticas públicas do poder Judiciário - audiência de custódia, prisão provisória e medidas cautelares: obstáculos institucionais e ideológicos à efetivação da liberdade como regra. Conselho Nacional de Justiça. 2018, p. 306. Disponível em: http://www.cnj.jus.br/files/conteudo/arquivo/2018/03/f78b252321b7491ffbbf9580f67e8947. pdf. Acesso em: 27 set. 2019.

BRASIL. Diagnóstico Veps Junho 2017. Conselho Nacional de Justiça. Disponível em: https://www.cnj.jus.br/files/conteudo/ arquivo/2018/09/7876afd7a270c1d26c331dd554d17f18.pdf. Acesso em: 20 set. 2019.

BRASÍLIA. Decisão cautelar na ADPF/DF n 347 no Supremo Tribunal Federal-STF. 2015, p. 7. Disponível em: http://portal.stf.jus. br/processos/downloadPeca.asp?id=312067308\&ext=.pdf. Acesso em: 2 out. 2018.

BRASÍLIA. Ação Declaratória De Constitucionalidade $n^{\circ} 43$. Distrito Federal. Relator: ministro Marco Aurélio. Supremo Tribunal Federal-STF. 2016a, p. 30. Disponível em: http://www.stf.jus.br/arquivo/cms/noticiaNoticiaStf/anexo/ADC43EF.pdf. Acesso em: 24 nov. 2019.

BRASÍLIA. Ação Declaratória de Constitucionalidade 44. Distrito Federal. Relator: Ministro Marco Aurélio. Supremo Tribunal Federal-STF. 2016b, p. 22. Disponível em: http://www.stf.jus.br/arquivo/cms/noticiaNoticiaStf/anexo/ADC44.pdf. Acesso em: 24 nov. 2019.

CAMPOS. Carlos Alexandre de Azevedo. Devemos temer o estado de coisas inconstitucional? Conjur. 2015. Disponível em: https://www.conjur.com.br/2015-out-15/carlos-campos-devemos-temer-estado-coisas-inconstitucional. Acesso em: 15 out. 2018.

COLÔMBIA. Corte Constitucional. Sentencia de Tutela 025. 2004. Disponível em: http://www.corteconstitucional.gov.co/relatoria/2004/t-025-04.htm. Acesso em: 15 set. 2018.

COLÔMBIA. Corte Constitucional. Sentencia de Unificación 559. 1997. Disponível em: http://www.corteconstitucional.gov.co/ relatoria/1997/SU559-97.htm. Acesso em: 10 out. 2018.

COLÔMBIA. Unidad para la Atención y Reparación Integral a las Víctimas. Estado de Cosas Inconstitucional (ECI)-Sentencia T-025. 2018. Capítulo 6. Disponível em: https://repository.oim.org.co/bitstream/handle/20.500.11788/975/Capitulo\%2006. pdf?sequence=10\&isAllowed=y. Acesso em: 9 set. 2018.

GIORGI, Raffaele de; VASCONCELOS, Diego de Paiva. Os fatos e as declarações: reflexões sobre o Estado de Ilegalidade Difusa. Revista de Direito Práxis Dossiê Questões Amazônicas, Rio de Janeiro, v. 9, n. 1, 2018, p. 480-503. Disponível em: http://www. scielo.br/scielo.php?pid=S2179-89662018000100480\&script=sci_abstract\&tlng=pt. Acesso em: 11 nov. 2018.

HESSE, Konrad. A força normativa da Constituição. Tradução Gilmar Ferreira Mendes. Porto Alegre: Editora Sérgio Antonio Fabris Editor, 1991. p. 31.

LYONS, Josefina Quintero; MONTERROZA, Angélica Matilde Navarro; MEZA, Malka Irina. La Figura del estado de cosas inconstitucionales como mecanismo de protección de los derechos fundamentales de la población vulnerable en Colombia. Revista Jurídica Mario Alario D'Filippo, Universidad de Cartagena, v. 3, n. 1, p. 69-80, 2011. Disponível em: https://dialnet.unirioja.es/ revista/21880/A/2011. Acesso em: 11 dez. 2018.

OMMATI. José Emílio Medauar. De legislador negativo a legislador positivo: as sentenças intermediárias no controle de constitucionalidade brasileiro. Revista do Ministério Público do RS, Porto Alegre, n. 80, p. 55-68, maio/ago. 2016.

RAMÍREZ, Mateo Gómez. El estado de cosas inconstitucional análisis de los motivos de la corte constitucional para su declaratória. Universidad Pontificia Bolivariana Escuela de Derecho y Ciencias Políticas Facultad de Derecho Medellín. 2010. Trabajo de grado para optar al título de Abogado, p. 61. Disponível em: https://repository.upb.edu.co/bitstream/handle/20.500.11912/83/TRABAJO\%20DE\%20GRADO.pdf?sequence=1. Acesso em: 12 out. 2108.

REVORIO. Francisco Javier Díaz. El control de constitucionalidad de las omisiones legislativas relativas en el derecho comparado Europeo. Revista Española de Derecho Constitucional, año 21, núm. 61, enero/abr. 2001, p 81-130. Disponível em: https:// www.jstor.org/stable/24884176?seq=1\#page_scan_tab_contents. Acesso em: 11 dez. 2018.

SARAMAGO, José. Ensaio sobre a cegueira. São Paulo: Editora Companhia das Letras, 1995. p. 312.

STRECK, Lenio Luiz. Estado de Coisas Inconstitucional é uma nova forma de ativismo. Conjur. 2015. Disponível em: https:// www.conjur.com.br/2015-out-24/observatorio-constitucional-estado-coisas-inconstitucional-forma-ativismo. Acesso em: 15 out. 2018.

SOUZA. Luiz Henrique Boselli de. Sentenças Aditivas na jurisdição constitucional. Revista Jurídica da Escola Superior do Ministério Público de São Paulo ESMP-SP, v. 3, p. 99-117, 2013. Disponível em: http://www.esmp.sp.gov.br/revista_esmp/index.php/ RJESMPSP/article/view/77. Acesso em: 1ㅇa. 2018.

VASCONCELOS, Diego de Paiva. A (dis)funcionalidade do Estado de Coisas Inconstitucional (ECI); estrutura da decisão e os limites funcionais do direito. Revista Conpedi Law Review, Braga - Portugal, v. 3, n. 2, p. 285-306, 2017. Disponível em: http:// portaltutor.com/index.php/conpedireview/article/view/480. Acesso em: 11 out. 2018.

ZAFFARONI, Eugenio Raúl; PIERANGELI, José Henrique. Manual de direito penal brasileiro: parte geral I. 4. ed. São Paulo: Revista dos Tribunais, 2011. 658p. 